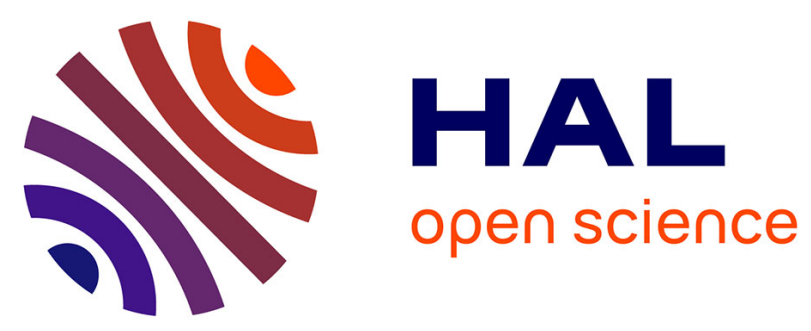

\title{
Influence of the slicing technique on mechanical properties of the produced veneer
}

Alexander Pfriem, Beate Buchelt

\section{To cite this version:}

Alexander Pfriem, Beate Buchelt. Influence of the slicing technique on mechanical properties of the produced veneer. European Journal of Wood and Wood Products, 2010, 69 (1), pp.93-99. 10.1007/s00107-010-0410-5 . hal-00561305

\section{HAL Id: hal-00561305 https://hal.science/hal-00561305}

Submitted on 1 Feb 2011

HAL is a multi-disciplinary open access archive for the deposit and dissemination of scientific research documents, whether they are published or not. The documents may come from teaching and research institutions in France or abroad, or from public or private research centers.
L'archive ouverte pluridisciplinaire HAL, est destinée au dépôt et à la diffusion de documents scientifiques de niveau recherche, publiés ou non, émanant des établissements d'enseignement et de recherche français ou étrangers, des laboratoires publics ou privés. 


\title{
Influence of the slicing technique on mechanical properties of the produced veneer
}

\author{
Alexander Pfriem, Beate Buchelt ()) \\ Technische Universität Dresden, Institute of Wood and Paper Technology, 01062 Dresden, \\ Germany \\ Email: beate.buchelt@tu-dresden.de
}

\begin{abstract}
:
The aim of this investigation was to compare the mechanical behaviour of lengthwise and plain sliced veneer of the species beech (Fagus sylvatica L.). Therefore, tension tests parallel and perpendicular to the grain were carried out. The results were evaluated using the variance analysis (ANOVA). As a result it can be stated that lengthwise sliced veneers exhibit significantly higher strength and better mechanical characteristics than plain sliced veneers. The checks parallel to the grain which occurred by manufacturing at that side of the veneer leaf which faces the cutting edge and which is stressed in tension are to be considered as reason therefore. In contrast to the tests parallel to the grain the modulus of elasticity perpendicular to the grain shows significantly lower values for lengthwise sliced veneers than for plain sliced veneers. Due to their higher strength values lengthwise sliced veneers are considered better base materials for engineered wood products than plain sliced veneers.
\end{abstract}

\section{Einfluss der Schnitttechnologie auf die mechanischen Eigenschaften der hergestellten \\ Furniere}

Zusammenfassung:

Ziel dieser Untersuchungen war der Vergleich des mechanischen Verhaltens von längs- und quergemesserten Furnieren der Holzart Rotbuche (Fagus sylvatica L.). Dazu wurden Zugversuche parallel und senkrecht zur Faserrichtung durchgeführt. Die Ergebnisse wurden mit der Varianzanalyse (ANOVA) verglichen. Längsgemesserte Furniere zeigen eine signifikant höhere Festigkeit und bessere mechanische Eigenschaften als quergemesserte Furniere. Als Grund dafür werden herstellungsbedingte Risse parallel zur Faser bei quergemesserten Furnieren angesehen. Längsgemesserte Furniere weisen senkrecht zur Faserrichtung überraschenderweise einen signifikant geringeren E-Modul auf als quergemesserte Furniere. Aufgrund ihrer höheren Festigkeitseigenschaften sind längsgemesserte Furniere besser für die Herstellung neuartiger Furnierwerkstoffe, wie Engineered Wood Products, geeignet als quergemesserte Furniere. 
Ejwwp410_source

\section{Introduction}

The application of veneer represents a very efficient method using wood from a tree. There are two different techniques in veneer production, the rotary cutting and the slicing technique. In generally, high-quality and decorative veneers are produced by slicing and different combinations of slicing and rotary cutting techniques, respectively (Kollmann 1962). Thereby the way of the cutting edge is usually perpendicular to the grain of the wood (plain slicing), because due to the short stroke ways high process velocities are possible. With this way of cutting the veneer is strongly bent immediately behind the cutting edge contact in order to guarantee further cutting until cut off of the veneer leaf from the flitch. Thus, checks occur in consequence of the strong bending stress during rotary cutting and plain slicing and low strength perpendicular to the grain. These checks occur parallel to the grain at that side of the veneer leaf which faces the cutting edge and which is stressed in tension (Shupe et al. 1997, Buchelt and Wagenführ 2007). The side with checks is called the loose side of a veneer. These checks can be a result of coating problems with liquid systems like adhesives or lacquers.

An alternative cutting technique is the so called lengthwise slicing where the cutting edge runs parallel to the grain (Schramm 2003). This cutting technique also results in bending stresses in the veneer leaf but parallel to the grain. In this grain direction the strength of the wood is a multiple of the strength perpendicular to the grain, so that no damage of the veneer is to be expected. Admittedly the long stroke ways of the knife about the whole length of the flitch leads to slower process velocities. That is why the economics is lower in comparison with the plain slicing technique.

The development of new veneer-based composites for loadable structural elements requires knowledge of the mechanical properties of the veneers. The aim of these investigations was a comparative analysis of the mechanical behaviour of the lengthwise and plain sliced veneer. The different cutting ways and the thus resulting stress of the veneer suggest differences in the mechanical characteristics of the veneers.

\section{Materials and methods}

\subsection{Materials}

The investigations were carried out with veneer from one trunk (length about $3 \mathrm{~m}$ ) of the species beech (Fagus sylvatica L.). This trunk was quartered along its trunk axis (Fig. 1). Two 
Ejwwp410_source

quarters of the trunk were plasticized with hot water $\left(80^{\circ} \mathrm{C}\right)$ for one week and subsequently sliced on an industrial plain slicing machine (VS4000 slicing machine) from the Danzer company in Melnik. The flat quarter cutting was used (Lohmann 2003) (Fig 1). These veneers were dried in a press dryer at $75-90{ }^{\circ} \mathrm{C}$ for approximately 2 hours.

The remaining two quarters were plasticized in a warm water bath at an average temperature of $70^{\circ} \mathrm{C}$ for 14 days. Then they were lengthwise sliced into veneers using a lengthwise slicing machine (Amitec FV 13) (Fig 1). These veneers were manually dried at a temporary pressure and temperature exposure $\left(140^{\circ} \mathrm{C}\right)$ for 2 to 3 minutes.

The reference thickness of the veneers amounted to $0.5 \mathrm{~mm}$ for both techniques. The flitches were prepared in that way that all veneers were cut in the cutting plane "longitudinal / tangential" (Fig. 1).

\section{Figure 1}

\subsection{Measurements and analyses of mechanical properties}

In each case, about 20 veneer leafs were randomly removed from the veneers produced with both slicing techniques. From each leaf ten samples were cut, five samples for the tension tests parallel to the grain and five samples for the tension test perpendicular to the grain. Therefore, a veneer cutting machine (Datacut) was used. The dimensions of the samples were $120 \mathrm{~mm} \times 14 \mathrm{~mm} \times 0.5 \mathrm{~mm}$ (longitudinal x tangential $\times$ radial for the tests parallel to the grain and tangential $\mathrm{x}$ longitudinal $\mathrm{x}$ radial for the tests perpendicular to the grain, respectively). All samples were conditioned to $22^{\circ} \mathrm{C} / 60 \%$ relative humidity and tested under the same conditions. The tension tests were carried out using a universal testing machine, where the samples are tensioned until failure. The strain measurement was carried out with a video extensometer (Fa. Messphysik, Austria) by capturing continuous images of the specimen during the test, using a frame grabber camera attached to a PC. In the area of clamping the veneer samples were reinforced with adhesive tape. The clamping pressure was adjusted for all tests by a constant clamping torque. It was $2 \mathrm{Nm}$ for the tests perpendicular to the grain and $3 \mathrm{Nm}$ for the tests parallel to the grain. This clamping torque was determined in pre-tests and guaranteed minimal damages of the samples in the area of clamping.

Tensile strength, strain to rupture, and modulus of elasticity (MOE) were determined by analysing all stress-strain-curves. MOE was determined by a linear regression between $0.05 \%$ and $0.25 \%$ elongation. The results were illustrated in box plots displaying five-point summaries (median, the two quartiles and the two extreme values) for the evaluation. 
Ejwwp410_source

All test series were evaluated statistically. In order to analyze significant differences between the mechanical properties of the veneers produced by the various slicing techniques, an „,analysis of variance test“ (ANOVA-test) with ,two-random sample F-test“ was carried out (Fahrmeir et al. 2004). The level of significance was chosen with $5 \%$.

\section{Results and Discussion}

\subsection{Results of tests parallel to the grain}

Figure 2 shows the results of the mechanical properties parallel to the grain for the veneers made by both slicing techniques. The calculated mean values and standard deviations of the mechanical characteristics are shown in Table 1.

\section{Table 1}

\section{Figure 2}

The mean value of the tensile strength (Fig. 2a, Table 1) of the lengthwise sliced veneers is approximately $16 \%$ higher than the tensile strength of the plain sliced veneers. This difference was confirmed as significant from the ANOVA-test. The tensile strengths of both variants, however, are in the range described by Wagenführ (2000) for solid wood (tensile strength of solid beech wood: 57 - $180 \mathrm{MPa}$ ).

In contrast, the values of the strain to rupture (Fig. 2b) do not exhibit a significant difference between both slicing techniques, as can be seen from the evaluation of the ANOVA-test. The MOE (Fig. 2c) is significantly higher for lengthwise sliced veneers than for plain sliced veneers. However, the mean values differ only by approximately $10 \%$ (Table 1 ).

\section{Figure 3}

Fig. 3 shows the stress-strain-curves of two tests exemplarily and comparatively. Both the lengthwise sliced and the plain sliced samples show the known rough behaviour of wood with the typical stress-strain-curves (Bodig and Jayne 1993).

In summery it can be assessed that the lengthwise sliced veneers have a higher strength and stiffness than the plain sliced veneers, whereas the strain to rupture does not differ. 
Ejwwp410_source

\subsection{Results of tests perpendicular to the grain}

Figure 4 shows the results of the mechanical properties perpendicular to the grain for the veneers made by both slicing techniques. The calculated mean values and standard deviations of the mechanical characteristics are shown in Table 2.

\section{Table 2}

\section{Figure 4}

The mean value of the tensile strength (Fig. 4a, Table 2) of the lengthwise sliced veneers is approximately $21 \%$ higher than the tensile strength of the plain sliced veneers. This difference was confirmed as significant from the ANOVA-test.

The values of the strain to rupture (Fig. 4b) also exhibit a significant difference between both slicing techniques. The mean value of the strain to rupture of the lengthwise sliced veneers is approximately $23 \%$ higher than the strain to rupture of the plain sliced veneers (Table 2 ). The authors ascribe this behaviour to pre-damages due to the slicing technology. Microscopical investigations verify checks in the surface of plain sliced veneers (Fig. 5 below). The lengths of these checks amounted to $100 \mu \mathrm{m}$. The lengthwise sliced veneers did not show such checks (Fig. 5 top). Thus the checks can be regarded as being responsible for the reduced strength and strain.

\section{Figure 5}

In contrast to the tests parallel to the grain, the MOE astonishingly shows significantly lower values for lengthwise sliced veneers (Fig. 4c) than for plain sliced veneers. The mean value of the MOE of the plain sliced veneers is approximately $41 \%$ higher than the MOE of the lengthwise sliced veneers (Table 2). The raised MOE cannot be explained by the checks. Likewise investigations using an optical 2-D-strain measurement method (Vic 2D) based on grey scale value correlation did not support an explanation for the raised MOE of plain sliced veneers.

The stress-strain-curves show different characteristic courses for lengthwise and plain sliced veneers. Table 3 shows typical stress-strain-curves of plain and lengthwise sliced veneers perpendicular to the grain.

\section{Table 3}


Ejwwp410_source

The most recorded typical curves are exemplary shown in Figure 6 for both slicing variants. Most of the lengthwise sliced samples exhibit continuously increasing course of the stress to the strain.

When looking at the typical curve of plain sliced veneers, it can be seen that at first the stress strongly increases under tension load until a first maximum. Thus a comparatively high MOE is calculated. Afterwards the stress decreases with further load. A clear second stress increase follows before the crack occurs. The curve resembles the stress-strain-curve of a ductile polymer (Michler 1992) but shows no typical material behaviour of wood. Though, the reached strain to rupture is comparatively low. The observed material behaviour of plain sliced veneer may have different causes. One reason could be found in pre-damages (checks) of the veneer due to the slicing technique, which influences the material behaviour. On the other hand there may be influences caused by the clamping devices for thin and flexible materials.

\section{Figure 6}

\section{Conclusion}

In order to analyse the mechanical properties of lengthwise and plain sliced veneers tension tests perpendicular and parallel to the grain were carried out. The results were evaluated using the variance analysis (ANOVA). In summery the following results can be formulated: Lengthwise sliced veneers exhibit significantly higher strength both perpendicular and parallel to the grain.

Considering the strain to rupture and the MOE no uniform tendencies can be found. The values of the strain to rupture of both lengthwise and plain sliced veneers lie in the same range as the load parallel to the grain. In contrast, perpendicular to the grain the strain to rupture of lengthwise sliced veneer is significantly higher than that of plain sliced veneer. Analogue to the strength the MOE is higher parallel to the grain than perpendicular to the grain.

Altogether the mechanical characteristics are better for lengthwise sliced veneers. The checks parallel to the grain occurring by manufacturing at that side of the veneer leaf which faces the cutting edge and which is stressed in tension are to be considered as reason therefore.

Since the lengthwise slicing technology requires clearly longer process times (because of its longer cutting paths) than the plain slicing technology it will not be accomplished for mass products like furniture in future. Due to their higher strength values the lengthwise sliced veneers are considered better base materials for wood products, which require high 
Ejwwp410_source

mechanical properties, e.g., engineered wood products and new veneer-based composites, than plain sliced veneers.

\section{References}

Bodig J, Jayne BA (1993) Mechanics of wood and wood composites. Krieger, Malabar, Florida

Buchelt B, Wagenführ A (2007) Untersuchungen zur Anisotropie der mechanischen Eigenschaften von

Nussbaummaserfurnier (Juglans nigra L.). Holz Roh- Werkst 65:407-409

Fahrmeir L, Künstler R, Pigeot I, Tutz G (2004) Statistik. Der Weg zur Datenanalyse. Springer, Berlin Heidelberg

Kollmann F (1962) Furniere, Lagenhölzer und Tischlerplatten. Springer, Berlin, Göttingen, Heidelberg

Lohmann U (ed.) (2003) Holz Lexikon Band 1 A-K. DRW-Verlag, Leinfelden-Echterdingen

Michler GH (1992) Kunststoff-Mikromechanik. Hanser, München Wien

Schramm A (2003) A complete guide to hardwood plywood and face veneer. Purdue University press, West Lafayette, USA

Shupe TF, Hse CY, Choong ET, Groom LH (1997) Effects of silvicultural practice and moisture content level on loblolly

pine veneer mechanical properties. Forest Prod J 47:92-96

Wagenführ R (2000) Holzatlas. Fachbuchverlag Leipzig im Carl Hanser Verlag, Leipzig 
Ejwwp410_source

\section{Figures}

Fig. 1 Schematic sketch of the test and used slicing technologies

Abb. 1 Prinzipskizze der Furniererzeugung und der verwendeten Furniermessertechnologien

Fig. 2 Comparison of (a) tensile strength, (b) MOE, and (c) strain to rupture parallel to the grain of the veneers produced by both slicing technologies

Abb. 2 Vergleich von (a) Zugfestigkeit, (b) E-Modul und (c) Bruchdehnung (c) von längs- und quergemesserten Furnieren parallel zur Faserrichtung

Fig. 3 Exemplary comparison of stress-strain curves parallel to the grain of the veneers produced by both slicing technologies

Abb. 3 Exemplarisch dargestellte typische Spannungs-Dehnungs-Verläufe von längs- und quergemesserten Furnieren parallel zur Faserrichtung

Fig. 4 Comparison of (a) tensile strength, (b) MOE, and (c) strain to rupture perpendicular to the grain of the veneers produced by both slicing technologies

Abb. 4 Vergleich von (a) Zugfestigkeit, (b) E-Modul und (c) Bruchdehnung (c) von längs- und quergemesserten Furnieren senkrecht zur Faserrichtung

Fig. 5 Light microscope image of the cross sections of a lengthwise sliced veneer sample (top) and a plain sliced veneer sample (below)

Abb. 5 Lichtmikroskopische Aufnahme des Querschnittes einer längsgemesserten Probe (oben) und einer quergemesserten Probe (unten)

Fig. 6 Exemplary comparison of stress-strain curves perpendicular to the grain of the veneers produced by both slicing technologies

Abb. 6 Exemplarisch dargestellte typische Spannungs-Dehnungs-Verläufe von längs- und quergemesserten Furnieren senkrecht zur Faserrichtung 
Ejwwp410_source

\section{Tables}

Table 1 Calculated mean values and standard deviations of mechanical properties of the veneers tested parallel to the grain for statistical evaluation (ANOVA)

Tabelle 1 Mittelwerte und Standardabweichungen der mechanischen Kennwerte der geprüften Furniere parallel zur Faser für die statistische Auswertung

Table 2 Calculated mean values and variances of mechanical properties of the veneers tested perpendicular to the grain for statistical evaluation (ANOVA)

Tabelle 2 Mittelwerte und Standardabweichungen der mechanischen Kennwerte der geprüften Furniere senkrecht zur Faser für die statistische Auswertung

Table 3 Assignment of stress-strain-curves of plain and lengthwise sliced veneers perpendicular to the grain to characteristic curves

Tabelle 3 Zuordnung der Spannungs-Dehnungs-Kurven der geprüften Furniere senkrecht zur Faserrichtung zu typischen Kurvenverläufen

Table 1 Calculated mean values and standard deviations of mechanical properties of the veneers tested parallel to the grain for statistical evaluation (ANOVA)

Tabelle 1 Mittelwerte und Standardabweichungen der mechanischen Kennwerte der geprüften Furniere parallel zur Faser für die statistische Auswertung

Plain sliced

Mean value Standard deviation Mean value Standard deviation
Number of evaluated tests

Tensile strength [MPa]

MOE [MPa]

Strain to rupture [\%]

\section{2}

100

12963

0.87
86

115

14302

0.88
26

1697

0.24

0.16

Table 2 Calculated mean values and variances of mechanical properties of the veneers tested perpendicular to the grain for statistical evaluation (ANOVA)

Tabelle 2 Mittelwerte und Standardabweichungen der mechanischen Kennwerte der geprüften Furniere senkrecht zur Faser für die statistische Auswertung

Plain sliced

Mean value Standard deviation Mean value Standard deviation
Number of evaluated tests

Tensile strength [MPa]

MOE [MPa]

Strain to rupture [\%]
81

3.32

673

1.05
0.78

198

0.22
86

4.02

0.62

477

154

1.29

0.33 
Ejwwp410_source

Table 3 Assignment of stress-strain-curves of plain and lengthwise sliced veneers perpendicular to the grain to characteristic curves

Tabelle 3 Zuordnung der Spannungs-Dehnungs-Kurven der geprüften Furniere senkrecht zur Faserrichtung zu typischen Kurvenverläufen

\begin{tabular}{|c|c|c|}
\hline Type of Stress-Strain-Curve & Plain sliced veneer & Lengthwise sliced veneer \\
\hline$\uparrow$ & 58 & 22 \\
\hline$\uparrow$ & 15 & 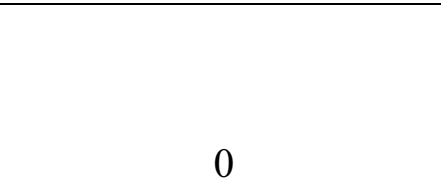 \\
\hline$\uparrow$ & 8 & 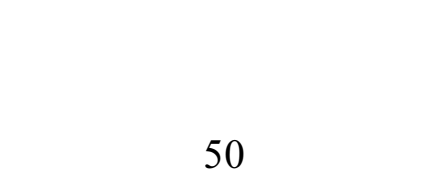 \\
\hline$\uparrow$ & 0 & 11 \\
\hline Other curves & 0 & 3 \\
\hline
\end{tabular}




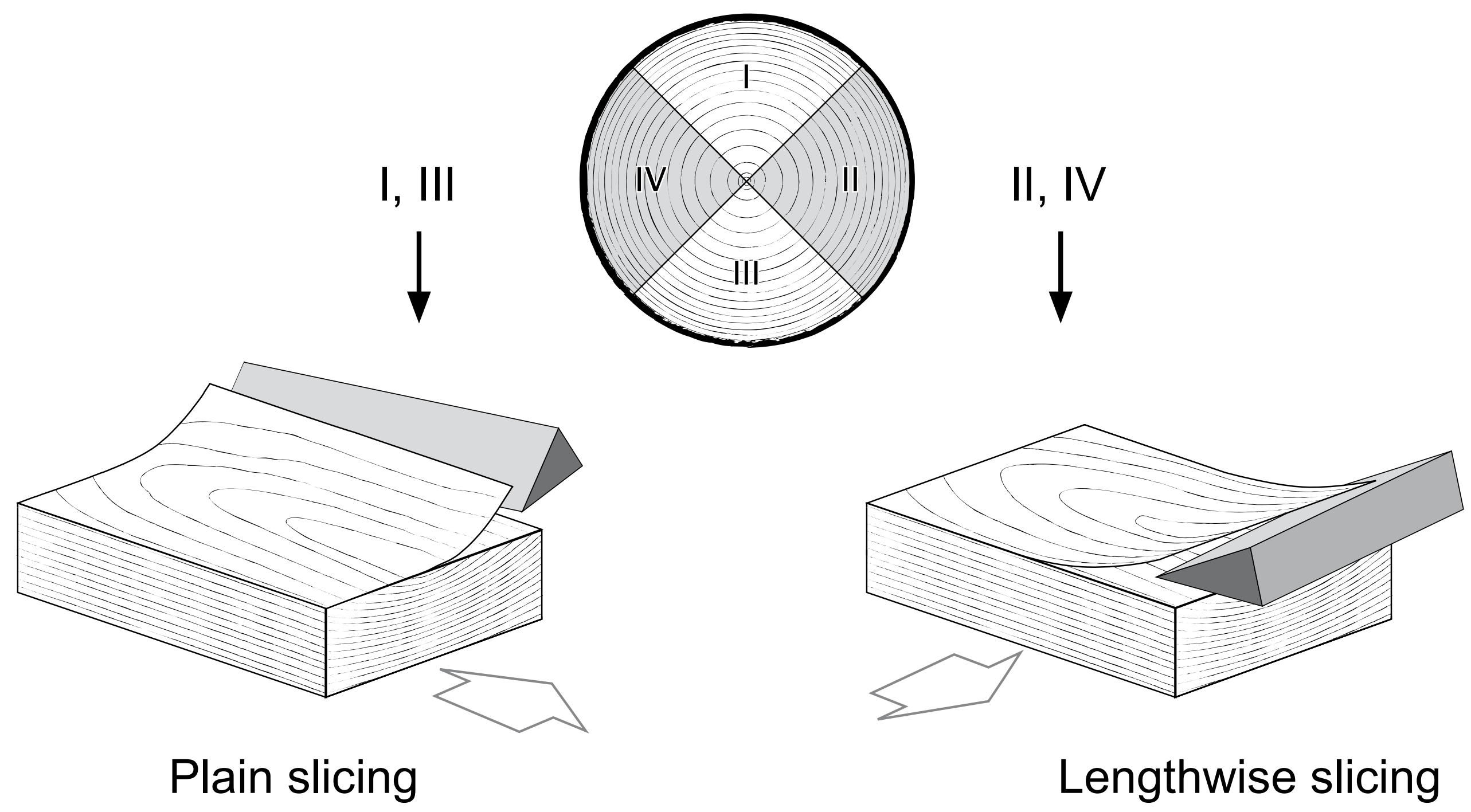



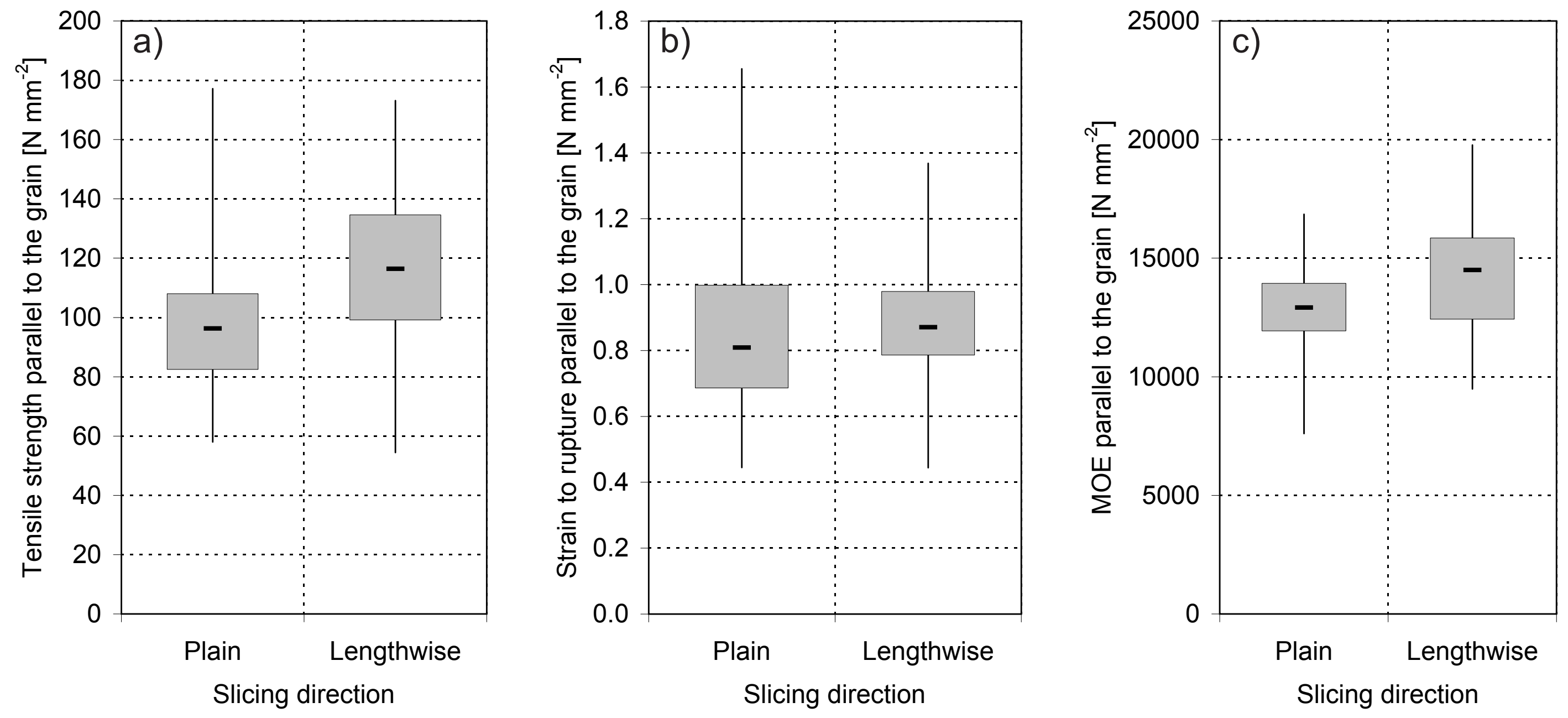


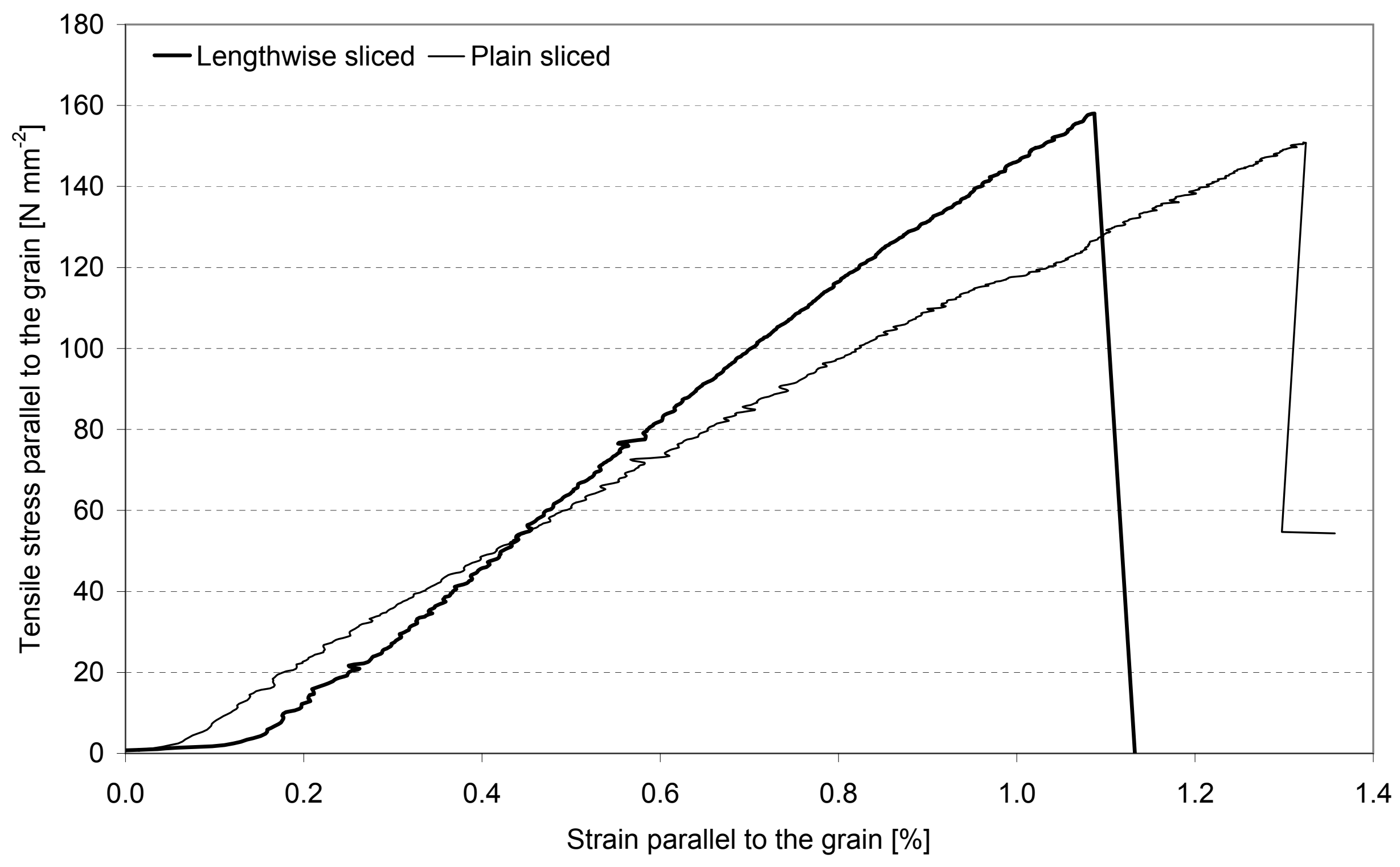



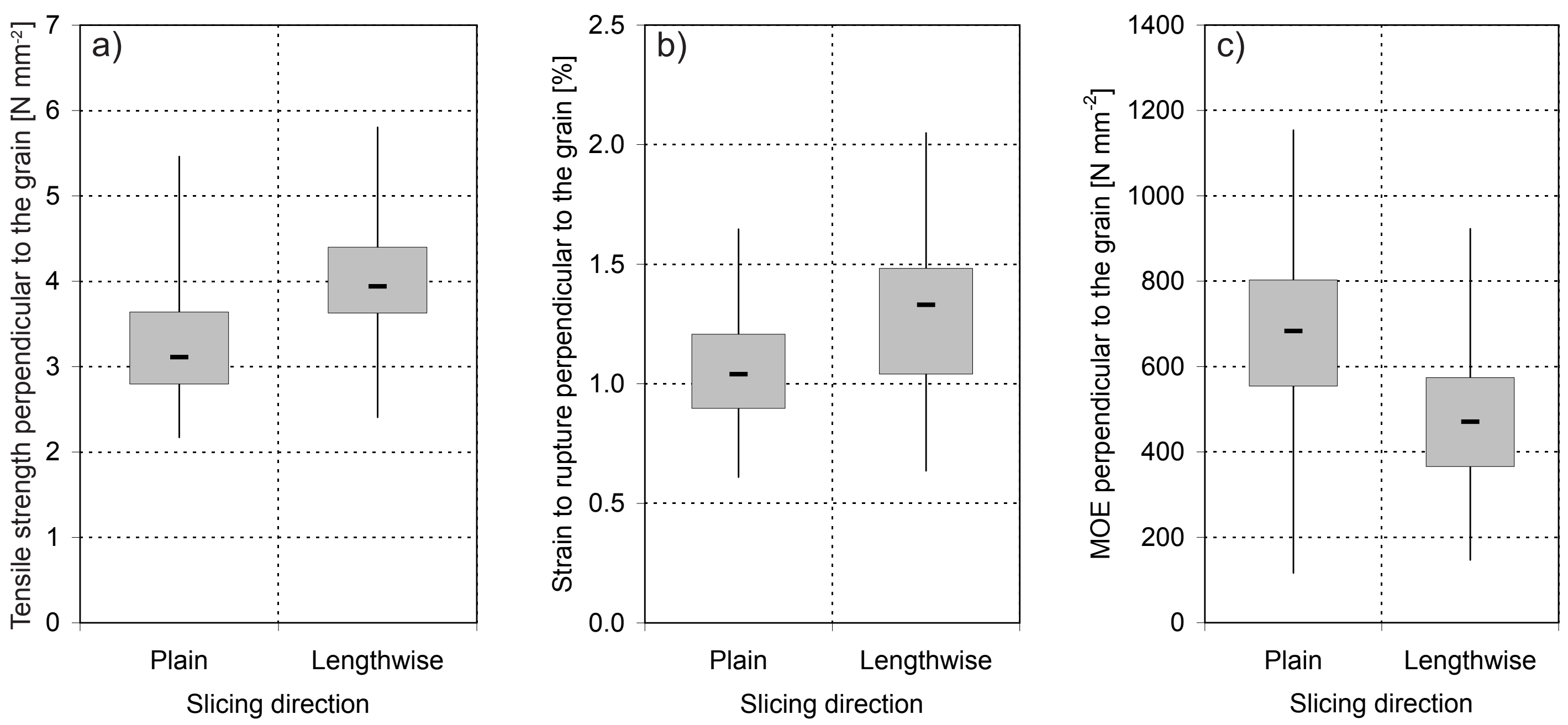
Fig 05 microscope image.jpg
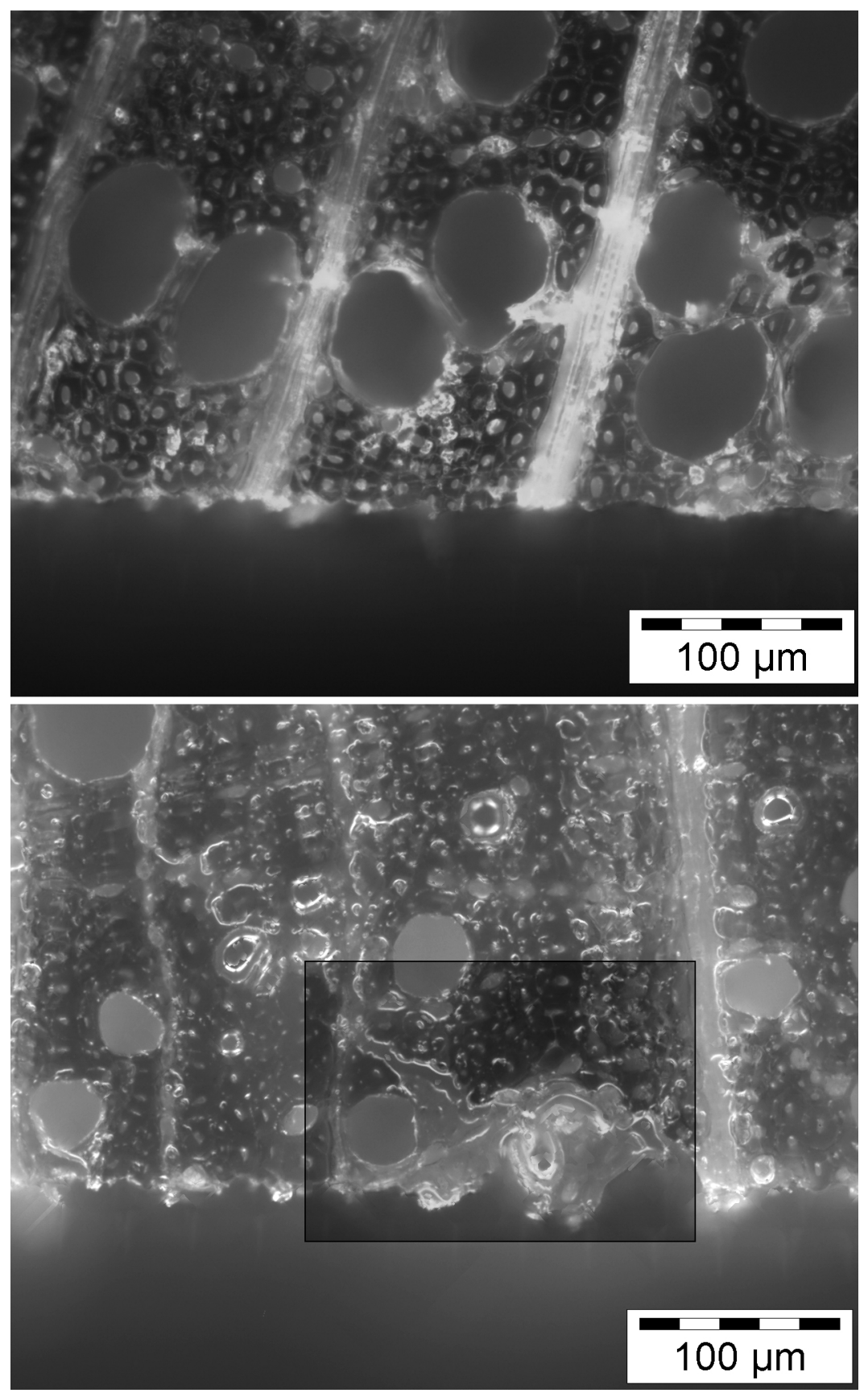


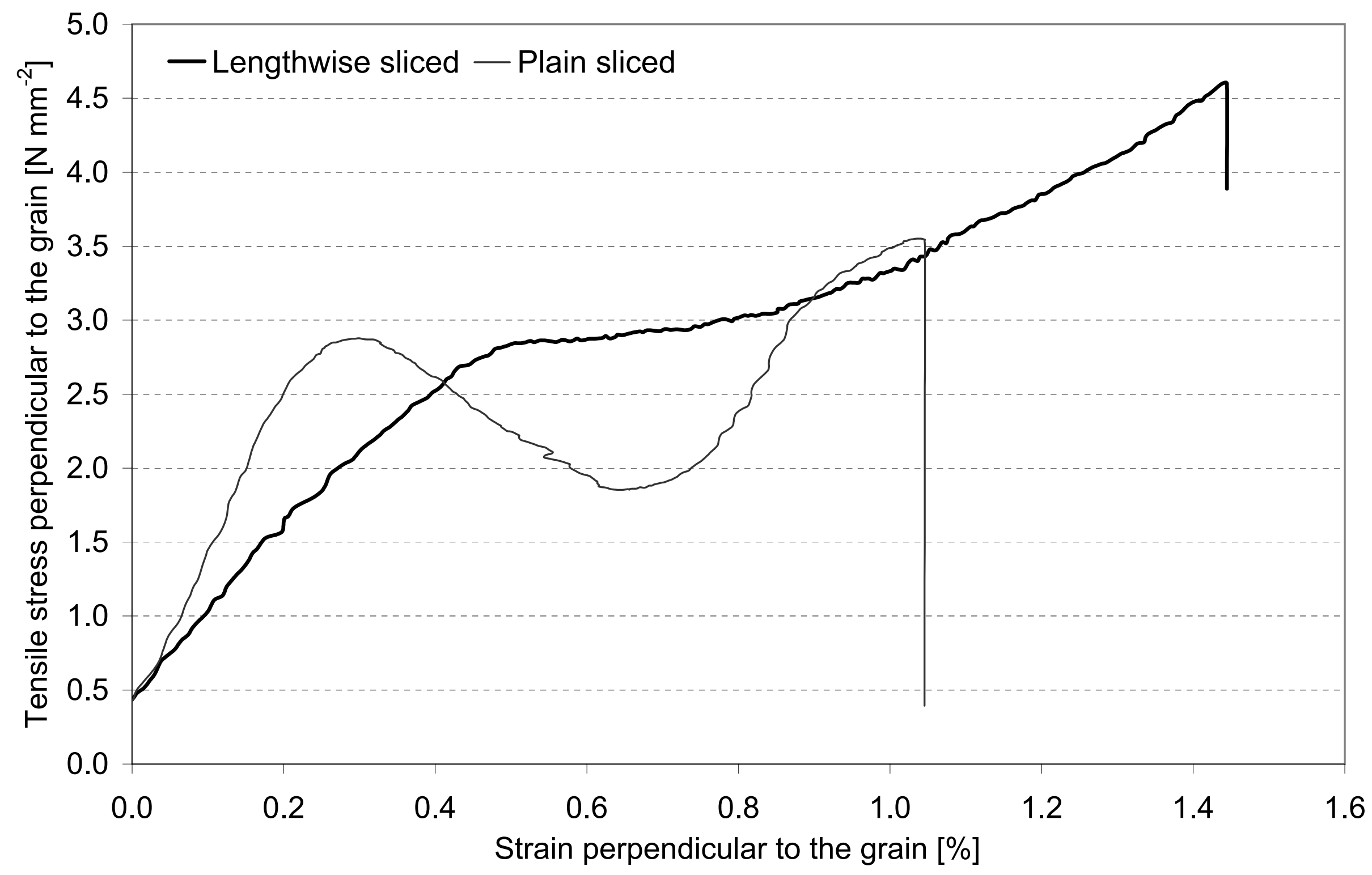

